\title{
Attitude of learners towards science and their science process skills in the case of the spiral curriculum: A literature review
}

\author{
Tinapay, Ariel \\ Cebu Roosevelt Memorial Colleges, Inc., Philippines (arieltinapay288@gmail.com) \\ Tirol, Shiela \\ Cebu Roosevelt Memorial Colleges, Inc., Philippines (shielatirol32@gmail.com) \\ Cortes, Jan Axel \\ DepEd Bogo City, Philippines (janaxelcortes23@gmail.com) \\ Punay, Marlinda \\ DepEd Bogo City, Philippines
}

Received: 27 September 2021

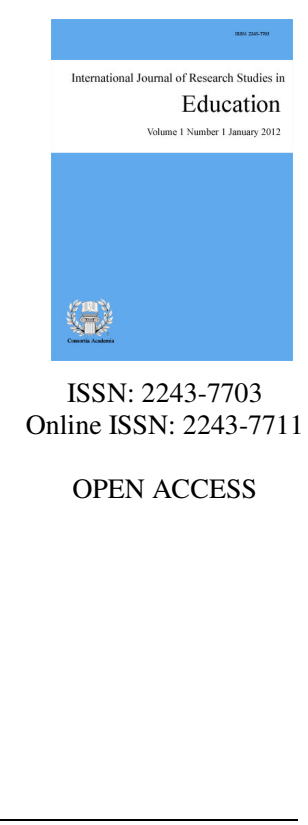

\section{Abstract}

This study aimed to determine the attitude of learners towards science and the science process skills of Junior High School Students of Cebu Roosevelt Memorial Colleges, Bogo City, Cebu for the school year 2020-2021. The review begins with a discussion of the factors of the learner's attitude towards science followed by a series of literature and studies. Presented also is the related literature of science process skills that affect the learner's attitude. Finally, a review related literature on the cognitive development theories of Piaget and of Bruner. The review concludes with the discussion of Piaget's theory of cognitive growth, which is concerned with the patterns of thought that affect a learner's attitude toward science.

Keywords: attitude, science process skills, spiral curriculum, institutional support, teaching assistance, experiential learning 


\section{Attitude of learners towards science and their science process skills in the case of the spiral curriculum: A literature review}

\section{Introduction}

This study discussed international and domestic concepts, generalizations and assumptions, methodologies, and other topics. Those in this study aid in getting a better perspective of the subject under review as well as familiarizing knowledge that is important and similar to the current analysis of learners' attitudes toward science and their science processing skills. This study aims to determine the learner's attitude towards science and their science process skills: the case of the spiral curriculum. The key themes presented in this work were embodied in the review of the literature and related studies. Administrators, teachers, students, parents and future researchers benefit through the findings from the literature review of this present study, providing the opportunity to systematically and collectively view the learning environment and conveying awareness towards science process skills as the learner's perceived.

\section{Learner's attitude towards science}

Attitude matters the most that's why it is necessary for learning. A person who is enthusiastic about science or some other topic that will stimulate students to concentrate on it, be motivated and interested. Learner's optimistic attitude towards science is a crucial field of educational research for some reasons, including the impact it can have on people's attitudes toward science and potential career choices. It also improves the acquisition of scientific knowledge and the development of science process skills. Students have a generally optimistic outlook toward research, but their science process skills are lacking (Mirana, 2019). Attitude towards science has always been a concern for science educators for having low levels of learning that might affect their opinions about science. When discussing these issues in science education, the term "attitude" is frequently used in a range of circumstances for them to realize the meaning of chosen study. When it comes to student attitudes toward information, the Science Technology Society strategy to teaching science works with both male and female students. In terms of improving optimistic reactions toward scientific research, no significant variations between male and female students were discovered (Akcay et al., 2010).

Students who were better at problem-solving had more positive attitudes toward science and a better understanding of how to incorporate complex problems into science instruction, which influenced the low and average systems. As a result, critical 21-century science teaching challenges and the need to encourage students' desire to study science are mutually beneficial. Molded by science, it shaped and powered by knowledge for unraveling the mysteries of the world of scientific phenomenon (Zeyer, 2017). After a project-based science program, minority learners' behaviors toward science deteriorated. There was still a lot of space to investigate the impact of teaching methods on students' behaviors. Furthermore, these interests or classroom management are unique to specific teaching acts. They are part of a larger trend of teaching styles like direct instruction (Kanter \& Konstantopoulos, 2010). This study aimed to see if there was a connection between students' attitudes toward science and their preference versus experience with collaborative versus direct instruction. Cooperative teaching methods such as group study in class or designing small-group projects were positively linked to attitudes toward science. Although previous research has shown that teaching strategy improves students' comprehension of science concepts, student attitudes toward school science tend to be more closely linked to social engagement or cooperation. The lack of a statistically relevant differential effect from instruction may also be attributed to our overall low rate of such instruction (Fulmer et al., 2019).

The understanding of students' attitudes influences their attitudes toward science, indicating that they have a high level of favorable attitudes toward career-oriented courses. While the study found that students' self-concepts of capacity, anxiety and fear have a strong influence on their attitudes toward physics, aspiration

14 Consortia Academia Publishing (A partner of Network of Professional Researchers and Educators) 
Attitude of learners towards science and their science process skills in the case of the spiral curriculum

has a moderate effect. Students, both male and female, had a slightly more optimistic understanding of science (Bang \& Baker, 2013).

Person, instructional, classroom management, and evaluation variables all had an impact on indigenous People students' academic success. Instructional and evaluation variables were the most consistent influences on academic success. Individual and instructional variables had a low association with indigent people's academic success, while classroom management and evaluation factors were negligible. The educational attainment of parents, lessons that relate to real-life circumstances, fun, and positive instructional correlation interactions, and significantly influence the academic success of indigent students were the most consistent items in the individual factors that affect administration (Andaya, 2016).

Factors affecting the poor performance of science subjects were the materials for teaching and learning are readily available and the environment of the school affects the pupil's academic performance. There are some schools not fit for science lessons thus, the school climate should be conducive to learning for parents, the administration, and society as a whole. Major problems faced by a teacher today involved the negative attitude of pupils towards science subjects. Pupils thought and complained that science was very hard as compared to other subjects which discouraged them, resulting in them getting a low performance. When it comes to modifying the curriculum, curriculum creators still have implementers. Despite the current pattern of revising the curriculum every five years, it could improve regularly. It ensures that implementers and other stakeholders are on the same page for students' performance to improve (King'aru, 2014).

Students enjoy demonstrations, applications, and realistic hands-on experimentation, according to a study of student attitudes toward science and mathematics, and they express positive attitudes toward science and mathematics after participating in these forms of classroom activities (Sanja et al., 2012). Students were able to develop both science and literacy skills as a result of the approach, which will help them in their future scientific studies. Students were able to communicate with their daily lives and bridge expectations thanks to the hands-on, outdoor activity. Preschool is an ideal time for children to participate in scientific discussion and investigation (Baldwin \& Wilson, 2017). Students with a positive outlook toward research are more interested in reflecting on the scientific method. To put it another way, as students grasp the science process skills, science becomes more important to them, resulting in increased positive attitudes toward learning (Zeidan \& Jayosi, 2015).

The evaluating dimension of success has a major relationship with communicating, inferring, and forecasting. Students who have mastered basic science process skills are more likely to apply the knowledge effectively, according to the results (Chebii, 2011). An analysis of prime students' analytical comprehension and alternate conceptions in the subject of acid-base showed that students struggled to understand the idea and had some misconceptions about the subject (Karadeniz, 2013). Students with a positive attitude toward science and strong process skills can see their cognitive abilities increase. Students' research process skills and attitudes toward science must also be developed using a scientific methodology. Students need to engage in research practices that are both hands-on and mind-on while studying science. Students love the hands-on activity because it allows them to develop, share, and realize their ideas, according to the study (Gomez-Arizaga et al., 2016).

In the last decade, student attitudes and expectations toward science have become a growing source of concern. Most of this stems from an increasing concern in advanced societies regarding students' lack of interest in continuing their studies in science. Since science attitude is such a complex construct, the chapter begins by reviewing research to establish guidelines for measuring it effectively. The general statement that there is a strong negative association between a country's development chart and student attitudes toward science is supported by the key features of individual students to science. To understand the dynamic pathways and choices that students make during their schooling, the influence of gender, teacher quality, and pre-adolescent experience on student attitudes and expectations toward science are explored in-depth, as well as a variety of other variables (Tytler \& Osborne, 2012). 
Students' optimistic attitudes toward scientific research, which encourages them to pursue science as a main topic. Integrated Science is an essential part of the Science Education Program since it prepares students to pursue science-related courses at institutions of higher learning. This reveals the students' thoughts, emotions, and values, as well as the characteristics of the factors that influence their attitudes (Oludipe \& Oludipe, 2010). While, other learners have been slacking when it comes to science. Male students were found to have a less optimistic outlook than female students. Students from urban areas have had a more optimistic outlook than students from rural areas (Ali, 2012). Students who were better at systems thinking had more positive attitudes toward science and a better understanding of how to incorporate complex problems into science instruction, which influenced the low and average systems. As a result, critical 21 st- century science teaching challenges and the need to encourage students' desire to study science are mutually beneficial. It was shaped by science and powered by experience to solve the mysteries of the world of scientific phenomena (Zeyer, 2017).

For several years, education has focused on the social, mental, and physical growth of children. Children are not interested in research skills and interactions because they do not fully comprehend what science entails. This was a major issue for teachers when teaching science to learners because they were often unfamiliar with teaching science and had little knowledge of the subject (Worth, 2010). Most school experiences can be particularly significant in easing the path to future careers in science. Primary and secondary school are critical periods for fostering students' interest in science. Some skills like observation still need to be taught in schools to be fully understood (Maltese et al., 2014). It allows the student to establish a relationship as well as the centered on students' development and self-concept. Students' involvement in science and their perception of its usefulness, which they value by believing that science provides a variety of benefits such as nurturing their talents, enhancing their abilities, and promoting careers, were found to be closely linked to their academic and career goals (Regan \& DeWitt, 2015).

With technical pedagogical material awareness, the relationship between scientific attitudes and research process skills. Simple science process skills had a positive interaction, while integrated science process skills had a bad encounter. Other components such as respect for evidence and truth, ability to change the paradigm, logical thinking, persevere, ambitious, imaginative, truthful, responsible, open-minded, objective, tolerant, cautious at work, and positive thinking do not display the expected engagement, which necessitates further discussion. With a positive scientific attitude that has consequences for their ability, scientific attitudes and basic science process skills interact positively with technical pedagogical material awareness (Juhji \& Nuangchalerm, 2020).

\section{Science process skills affect learner's attitude}

Science process skills (SPS) have been used at various times to describe science skill that as we imagine, they happen naturally and spontaneously in most of our minds. These abilities are described as a collection of abilities that can be applied to a wide range of science disciplines and represent scientific conduct. This phase of critical thought about the world and how to address our questions about how the world functions, whether consciously or unconsciously, required the application of science process skills (Malhi, 2017). Before applying the methods, the Science Process Skills (SPS) will help students gain strong mastery for successful science inquiry and hands-on science learning. These are the fundamental elements of scientific analysis and critical thought. Students had an average level of basic science process skills but a low level of integrated science process skills, according to the findings. This is reflected in a connection between students' science performance and basic SPS, which serves as a promising prospect based on their knowledge. Furthermore, there was a strong connection between students' overall science process skills and their science achievement. Students' science process skills can be improved by the application of science skills to real-world issues. As a result, students' achievement in science will be enhanced, and programs to promote and elevate students' achievement in science will be undertaken. This is critical for individuals living in a rapidly changing world, and teachers play a critical role in educating individuals with these skills to contribute significantly to society's change (Aydogdu et al., 2014).

16 Consortia Academia Publishing (A partner of Network of Professional Researchers and Educators) 
Science process skills allow enhancing learning in scientific field of study that provides a fantastic opportunity for all, specifically the pupils, to establish through scientific inquiry into their knowledge. When students understand what science is all about and how it works, they will be able to apply their science process skills as well as scientific content knowledge, which is required in any science curriculum (Duruk \& Akgun, 2016). In the course of teaching, a combination of science content knowledge and science process skills are requirements to achieve the objectives of science education which is to enhance scientific literacy among learners that will drive them to be aware, bold and competitive citizens can make fair judgments and wise decisions regarding the application of scientific knowledge that may have social, health or environmental impacts (K to 12 Science Curriculum Guide August 2016).

The research was undertaken to look at how teachers' science teaching experiences, behaviors, and science process skills have changed over time. It is obvious that science is beneficial to our daily lives and that it aids the professional development intervention as a result of years of continuous research. Teachers and students took part in an experimental process in this randomized controlled study, which included training on problem-based science curriculum units, inquiry-based teaching, classroom management, and technology usage in the classroom, as well as assistance in setting up an investigative classroom and integrating the science curriculum. To direct their classroom teaching, both experimental and comparative teachers used the state science frameworks (Dailey \& Robinson, 2017).

Argument-based science instruction, supplemented by authentic case studies, was thought to help students understand acid and base principles and improve scientific process skills. The educational achievement test in acids and bases, the Science Class Assessment Instrument, and the Scientific Process Skills test were given as a pre-test and a post-test before and after the application. When studying the topic of acids and bases, the argumentation-based science teaching method was more successful than the didactic method. The results demonstrated that the academic accomplishment of the students educated with an argumentation-based approach was higher than the ones taught with a didactic teaching approach (Ural et al., 2020). One of the tasks involving argumentation contributes to a better comprehension of the topic of acid-base. Several studies looked into the impact of an argumentation approach on students' learning and understanding of concepts in science classes. This includes the scientific process, which determines understanding levels (Karpudewan et al., 2016).

Science process skills are being used as a standard when preparing lessons to ensure that they are transparent and understandable. Science process skills, on the other hand, should not be taught as a stand-alone lesson since they must be linked to essential concepts and functions. As a result, science knowledge should serve as a background for lessons rather than taking up the entire lesson. Instead, more emphasis should be placed on activities that improve science process skills and improve understanding of science concepts. This means that process skills work in tandem with scientific expertise and attitudes to assist students in thinking in a systematic manner (Coronado, 2016). Hence, learning in science is a vital factor in providing resources for technical knowledge to be implanted. These abilities serve as a springboard for other cognitive abilities such as logical thinking and reasoning, which place a premium on providing consistent and actionable instructions to the task. To be motivated by discovery questioning, students should be informed of the science process skills that must be learned. This meant that teachers should often provide instruction to students during the experiment or lesson so that they understand they are learning to develop science process skills (Rauf et al., 2013).

Science Process Skills, which include observing, classifying, inferring, forecasting, communicating, and measuring, are the blocks of critical thinking and inquiry in science. Learners can acquire these skills through the science idea of this project. Students' comprehension of science process skills is low, according to the report, and there is a strong positive relationship between students' knowledge of science process skills and their attitudes toward physics. The researchers concluded that students should be exposed to science process skills for the betterment of their future lives and societies, and that the level of positive attitudes among students should be improved so that they can think, reflect, and associate with ideas related to any sciences. The teaching and learning of sciences have a significant impact on the attitudes of students (Kamba et al., 2018). 
Science education aims to improve the students' scientific analysis for gaining knowledge as well as the development of basic process skills for proper attitude and well- being. Students will be trained and get used to it for its advantages in society (Opulencia, 2011). Scientific understanding is what we can learn from the scientific method, which entails experimenting and gathering data, which includes hypotheses, concepts, and laws, which make up the substance of sciences. Science process skills are included in this scheme, which connects the parts to form a whole and is one of the ways to acquire information. Science process skills are the fundamental skills for promoting science learning, enabling students to be involved, participative, and competitive individuals to build a sense of obligation, increase learning permanence, and provide effective testing methods (Erturk \& Kaptan, 2010).

Society values science because it allows them to meet their needs and raise their living conditions through the application of scientific knowledge. It is often stressed how important it is for science-literate individuals to have scientific process skills and to use inquiry as a teaching method during lessons. People with more and better education will be able to apply new scientific findings in a more prosperous way. When the degree of incorporation of this approach is investigated in the books that serve as the primary resources for the courses, it is clear that the studies in the books appeared to be at the formal inquiry level. As a result, students can develop only rudimentary skills. By taking a critical look at the experiments in textbooks, aspiring classroom teachers will discover new experiments that they can create (Akben, 2014).

To provide more comprehensive information, science teachers' science process skill levels were evaluated in two phases, namely, basic and integrated process skills. According to the findings, science teachers' basic process skills were higher in percentage than their integrated process skills. Basic process skills outperformed integrated process skills by a wide margin. There was no statistically significant difference between teachers' basic and integrated process skills, but basic process skill scores were higher in terms of mean scores than integrated process skills (Miles, 2010).

Understanding of Science process is crucial for those who want to know about scientific ideas because its focus on learning a collection of skills or abilities that scientists must possess during the scientific discovery process, testing and acquiring new perspectives through specific skills. These abilities are classified into two categories: fundamental and integrated process abilities. Observing, asking questions, classifying, calculating, and forecasting are all critical process skills. Identifying and describing variables, analyzing data, manipulating objects, recording data, formulating theories, designing inquiries, and drawing inferences and generalizations are all integrated process skills (Karamustafaoglu, 2011).

A questionnaire was used to gather science process skills, which included both basic and integrated science process skills. And it was discovered that they had a moderate level of acquisition of science process skills, with no gender differences. It is beneficial to those interested in learning about the power of science (Al-rabaani, 2014). Scientific process skills were measured using the students' science process skills within a cognitive domain, and the results were generally poor. Because of the innovation and unique science methods available in the field, private school students scored higher than public and bussed school students (Ozgelen, 2012). In this regard, the incorporated science process skills entail the application of a variety of basic level skill areas, and the standard process skill is closely linked to observation (Sen \& Nakiboglu, 2012).

This plays an important role in the growth of students' science process skills as technology advances. There was, however, a major gap between students based on their parents' professions (Karar \& Yenice, 2012). Science understanding is made up of scientific processes and scientific attitudes. It has been discovered that students who possess scientific process skills are better able to solve problems, think objectively, make choices, and draw conclusions, as well as resolve their fears (Ergul et al, 2011). Science process skills are important for gaining scientific knowledge that can be applied to societal problems. In general, students' chemistry achievement was found to be low. Lack of exposure to scientific process skills is most likely to blame for the poor results. The impact of a science process skills teaching method on students' chemistry achievement was explored in this

18 Consortia Academia Publishing (A partner of Network of Professional Researchers and Educators) 
Attitude of learners towards science and their science process skills in the case of the spiral curriculum

research. Improvement of students' experimental method skills in terms of practicing or conducting experiments (Abungu et al., 2014).

Learning in science is an important factor to provide opportunities to implant scientific skills. These abilities serve as a springboard for developing other cognitive abilities like critical thinking and reasoning. In order to be motivated by discovery questioning, students should be informed of the science process skills that must be learned. This meant that teachers should always provide instruction to students during the experiment or lesson for them to understand what they are learning and to develop science process skills (Rauf et al., 2013). Students' attitudes toward science will change as a result of societal interests and educators' responsibilities, and they will be better prepared to live in a highly scientific and technical world. Science and technology have a significant effect on society and awareness development. People can comprehend and help form the diverse effects of science and technology on our planet will decide the future of our culture, as it will affect how we live and what we believe (Ungar, 2010). An approach to teaching the actions of doing science can be a highly successful teaching tool for students who struggle to grasp concepts and apply process skills. More students would be able to relate to the basic scientific method in this way (Yager \& Akçay, 2010).

By stressing basic process skills and assigning group tasks that require a collective effort, science-enhancing and student-centered techniques may be used to help students enhance their success. School funding is needed for the construction of more rooms for science-related activities such as laboratories and an e-classroom. More students will be persuaded, according to the study, and will attempt to explore the world of science in areas where they feel at ease. The same field of focus could be used to improve Science education, which would help students (Maranan, 2017).

\section{The spiral curriculum}

According to the curricular framework involved in spiral progression, the Spiral Progression Approach in Teaching Science in the K to 12-curriculum calls for new perspectives in the application of teaching and learning growth. It was necessary to go through the material again to get a better understanding of it. The exploration technique was an important teaching tool, and cooperative learning used the spiral progression method in science. Under the spiral progression approach, the use of multimedia and laboratory experiments was critical for students to gain a greater understanding of science concepts and their relevance to their daily lives (de Ramos-Samala, 2018). Individuals who are scientifically, technologically, and environmentally literate created the Science Curriculum Framework for Basic Education. Maintaining good health and living healthy, using resources and dealing with changes, conserving and preserving the environment, and using different real-life contexts across grade levels are the three central themes. The content-based science education program aimed to prepare students for a deeper understanding and application of science in their daily lives. The inquiry skills, whereby the primary grade students were introduced to the process of "hands-on minds-on," stage in which the students want to explore and ask some questions about the environment, were the first component of the curriculum components.

As the student progresses through the grades, he or she should be able to design and perform investigations that include defining and monitoring variables, collecting and organizing data, formulating theories or models, and making decisions based on sound judgment and rational reasoning. The second part was Scientific Attitudes, which relates to beliefs and behaviors that must be instilled in students from Grade 1 to Grade 10 for them to become active citizens. The final part was Content and Connections, which included three content areas: life science, physical science, and earth science, with an emphasis on understanding the connections and interrelationships between them. Learners will also learn and develop by participating in community needs, realizing the value of getting a solid understanding of scientific principles, being active citizens, and contributing to the improvement of their communities' quality of life (Brawner, 2011).

The new curriculum materials provided an effective way of learning to the students when taught by the 
teachers. Teachers' professional development integrated into the science curriculum focused on the elementary students understanding and skills and provided teachers knowledge content and effective way of teaching. The implementation of a new curriculum involved teacher professional development of knowledge and skills and was of great help in teaching science using new curriculum materials towards the pupil's activities. Strategies of the teacher's learning included examination work with the students, case discussion, and action research. Other issues concerned with student's work illustrating the development of inquiry abilities, using science technologies, and school program activities (Bybee, 2010).

The factor that caused poor academic performance relates to the poor English command among pupils, which hinders the students from understanding concepts, making sentences, understood terminologies of various subjects, and comprehending the question. Failure of a student to master English was the root cause in the student capacity of teachers to use the language. Due to a lack of therapy, students developed a negative self-image and lack of self-confidence. They were unable to handle test matters due to a lack of required research skills. All schools must implement therapy services, and the community and government must ensure that counselors are properly qualified to support students in schools (Maganga, 2016).

It identified and documented the learners' personal experiences and relayed their stories. The students' perspectives and observations toward the application of the Spiral Progression Approach in learning the Science subject were explored using a phenomenological framework. Furthermore, the learners were prepared to graduate from a program that promotes progressive, constructive, learner-centered, integrated, advanced, enhanced, and inquiry-based learning (Mangali et al., 2019). Since they were motivated and consistent to study even further, students' career goals were found to be difficult to alter. But, in some other cases, the student's lack of interest in science or any science-related careers is a concern worldwide. Thus, instead of focusing on increasing the number of students interested in science careers, educators may focus on fostering students' attitudes, such as their perception of science's usefulness, and/or using a variety of teaching and learning methods or activities to encourage or motivate students to explore the world of science (Archer et al., 2014).

\section{Synthesis}

Science education's purpose is to teach students not only how to improve their skills, but also how to understand how nature functions by studying its various aspects of science. Individuals will be encouraged to use those skills in their daily lives as a result of this program. Individuals' intimate, social, and global lives can be influenced by these abilities. Science Process Skills are an essential tool for producing scientific data, regardless of its possible application, and for developing knowledge and understanding to conduct scientific research and solve problems (Panoy, 2013). Science education has been working on the important aspect of inquiry of students' attitude to science subjects for a long run. Its importance is due to an alarming decline of students' attention towards scientific careers. So, they must do some actions and practices on how to develop and encourage more students. The importance of scientific knowledge, the falling number of choosing science has created an alarming situation. Now is a need for the time to recognize and construct a positive attitude towards the subject of science. The development of instructors' attitudes towards scientific approach plays in enhancement of learners' attitude (Lakshmi, 2014)

\section{References}

Abungu, H. E., Okere, M. I. O., \& Wachanga, S. W. (2014). The effect of science process skills teaching approach on secondary school students' achievement in chemistry in Nyando District, Kenya. Journal of Educational and Social Research, 4(6), 359-372. https://doi.org/10.5901/jesr.2014.v4n6p359

Akben, N. (2014). Improving science process skills in science and technology course activities using the inquiry method. International Research Journal of Library and Information Science.

Akcay, H., Yager, R. E., Iskander, S. M., \& Turgut, H. (2010). Change in student beliefs about attitudes toward science in grades 6-9. Asia-Pacific Forum on Science Learning and Teaching. 
Attitude of learners towards science and their science process skills in the case of the spiral curriculum

Ali, M. S. (2012). Effect of test anxiety and attitude towards science on students'achievement in science (Doctoral Thesis). Lahore: IER, University of the Punjab.

Al-rabaani, A. (2014). The acquisition of science process skills by Omani's pre-service social studies' teachers. European Journal of Educational Studies, 6(1), 13-19.

Andaya, J. (2016). The K-12 support system Pasig, Philippines. Department of Education. Retrieved from https//www.deped.gov.ph/sites/default/files/page/2016/J. AndayaEducationSummit.pdf

Archer, L. DeWitt, J., \& Dillon, J. (2014). 'It didn't really change my opinion': Exploring what works, what doesn't and why in a school science, technology, engineering and mathematics careers intervention. Research in Science \& Technological Education, 32(1), 35-55. https://doi.org/10.1080/02635143.2013.865601

Astalini, A. Kurniawan, D. Kurniawan, N., \& Anggrani, L. (2019). Evaluation of student's attitude toward science in Indonesia. Open Journal for Educational Research, 3(1), 1-12.

Aydoğdu, B. Erkol, M., \& Erten, N. (2014). The investigation of science process skills of elementary school teachers in terms of some variables. Asia-Pacific Forum on Science Learning and Teaching, 15(1), 8.

Baldwin, J., Ebert-May, D., \& Burns, D. (1999). The development of a college biology self-efficacy instrument for non-majors. Science Education, 83(4).

Baldwin, K., \& Wilson, A. (2017). Acting like rain: preK students engage in science talk and head outside to build earth science knowledge and process skills. National Science Teachers Association.

Bang, E., \& Baker, D. (2013). Gender differences in Korean high school students' science achievements and attitudes towards science in three different school settings. Mevlana International Journal of Education, 3(2), 27-42.

Black, L., \& Hernandez-Martinez, P. (2016). Re-thinking science capital: The role of 'capital' and 'identity' in mediating students' engagement with mathematically demanding programs at university. Teaching Mathematics and Its Applications, 35(3), 131-143. https://doi.org/10.1093/teamat/hrw016

Brawner, F. G. (2011). Science education institute, science framework for Philippine basic education, department of science and technology, University of the Philippines. National Institute for Science and Mathematics Education Development.

Bybee, R. (2010). Teaching science perspectives: 21st century, professional development and curriculum, and implementing the new curriculum (pp. 22-23).

Chebii, R. (2011). Effects of science process skills mastery learning approach on secondary school students' achievement and acquisition of selected chemistry practical skills in Koibatiek District Schools. Egerton University.

Chrappan, M. (2017). Teacher's attitudes and their methodological impact on learner's motivation. University of Debrecen, Hungary.

Coronado, R. B. (2016). Correlations between science process skills and test-taking abilities among grade viii students input in designing test matrix. Master's Thesis. Laguna State Polytechnic University, San Pablo City Campus.

Creswell, J. W. (2013). What is mixed methods research [video file]. Retrieved from https://www.youtube.com/watch?v=10aNiTlpyX

Cuaresma, L. D. (2014). Science curriculum related variables and academic performance of fourth year students of Los Banos Laguna. Master's Thesis. Laguna State Polytechnic University, San Pablo City Laguna.

Dailey, D., \& Robinson, A. (2017) Improving and sustaining elementary teachers' science teaching perceptions and process skills: A post-intervention study. Journal of Science Teacher Education, 28(2), 169-185. https://doi.org/10.1080/1046560X.2016.1277601

Duruk, O., \& Akgun, A. (2016). The investigation of pre-service science teachers' critical thinking dispositions in the context of personal and social factors. Science Education International, 27(1), 3-15.

Ergul, R., Simsekli, Y., Calis, S., Ozdilek, Z., Gocmencelebi, S., \& Sanli, M. (2011). The effect of inquiry-based science teaching on skill and science attitudes. Bulgarian Journal of Science and Education Policy (BJSEP), 5(1), 48-68.

Erturk, G., Bati, K., \& Kaptan, F. (2010). The awareness levels of pre-school education teachers regarding 
science process skills. Turkey.

Fulmer, G. W., Ma, H., \& Liang, L. L. (2019). Middle school student attitudes toward science, and their relationships with instructional practices: a survey of Chinese students' preferred versus actual instruction. Asia Pac. Sci. Educ., 5, 9. https://doi.org/10.1186/s41029-019-0037

Gogolin, L., \& Swartz, F. (1992). A quantitative and qualitative inquiry into the attitudes toward science of non-science college students.

Gomez-Arizaga, M. P., A. Kadir Bahar, Maker, C. J., Zimmerman, R., \& Pease, R., (2016). How does science learning occur in the implementation of the REAPS Model. Eurasia Journal of Mathematics, Science \& Technology Education, 12(3), 431-455.

Hacieminoglu, E. (2015). Elementary school students' attitude toward science and related variables. International Journal of Environmental \& Science Education, 11(2), 35-52.

Johnston, J. S. (2014). John Dewey and science education. Memorial University of Newfoundland.

Joyce, B. A., \& Farenga, S. J. (2015). Informal science experience, attitudes, future interest in science, and gender of high-ability students: An exploratory study. School Science and Mathematics, 99(8), 431-437.

Juhji, J., \& Nuangchalerm, P. (2020). Interaction between scientific attitudes and science process skills toward technological pedagogical content knowledge. Journal for the Education of Gifted Young Scientists, 8(1), 1-16. https://doi.org/10.17478/jegys.2020.XX

Kamba, A. H., Giwa A. A., Libata I. A., \& Wakkala, G. T. (2018). The relationship between science process skills and student attitude toward physics in senior secondary school in Aliero metropolis. African Educational Research Journal, 6(3), 107-113.

Kanter, D. E., \& Konstantopoulos, S. (2010). The impact of a project-based science curriculum on minority student achievement, attitudes, and careers: The effects of teacher content and pedagogical content knowledge and inquiry-based practices. Science Education, 94, 855-887.

Karadeniz Bayrak, B. (2013). Using two-tier test to identify primary students' conceptual understanding and alternative conceptions in acid base. Mevlana International Journal of Education (MIJE), 3(2), 19-26. https://doi.org/10.13054/mije.13.21.3.2

Karamustafaoğlu, S. (2011). Improving the science process skills ability of science student teachers using I Diagrams. Eurasian J. Phys. Chem. Educ. 3(1), 26-38.

Karar, E., \& Yenice, N., (2012). The investigation of scientific process skill level of Elementary education 8th grade students in view of demographic features. Procedia - Social and Behavioral Sciences, 46, $3885-3889$.

Karpudewan, M., Roth, W., M., \& Sinniah, D. (2016). The role of green chemistry activities in fostering secondary school students' understanding of acid-base concepts and argumentation skills. Chemistry Education Research and Practice, 17, 893-901. https://doi.org/10.1039/C6RP00079G

Kendra, C. (2014). Piaget's stages of cognitive development. Background and key Concepts of Piaget's Theory. Retrieved from http://psychology.about.com/od/piagetstheory/a/keyconcepts.html

King'aru, J. M. (2014). Factors contributing to poor performance of science subjects: A case of secondary schools in Kawe Division, Kinondoni Municipality. Open University of Tazania.

Kumarrasammy, K. (2017). Teachers' perceptions of infusion of values in science lessons: A qualitative study, research in science education.

Lakshmi, G. B. (2014). Attitude towards science. New Delhi, India: Discovery Publishing.

Maganga, J. (2016). Factors affecting students' academic performance: Case study of public secondary schools in Ilala District, Dar-Es-Salaam, Tanzania. Master Degree in Education Administration, Planning and Policy Studies of the Open University of Tanzania.

Malhi, R. K. (2017). Skill development is key to economic progress - Role of higher education in India. International Journal of Innovative Research and Advanced Studies (IJIRAS), 4(3), 174-177.

Maltese, A, Melki, C, \& Wiebke, H. (2014). The nature of experiences responsible for the generation and maintenance of interest in STEM. Science Education, 98(6), 937-962. https://doi.org/10.1002/sce.21132

Mangali, G., Tongco, C., Pamela, A., \& Calvadores, C. (2019). Stories of students toward spiral progression approach in science: A phenomenological study. International Journal of Multidisciplinary Research

22 Consortia Academia Publishing (A partner of Network of Professional Researchers and Educators) 
Attitude of learners towards science and their science process skills in the case of the spiral curriculum

and Publications, 2, 37-48.

Maranan, V. M. (2017). Basic process skills and attitude toward science: Inputs to an enhanced student cognitive performance. Retrieved from https://files.eric.ed.gov/fulltext/ED579181.pdf

McLeod, S. A. (2019). What is Psychology? Retrieved from https://www.simplypsychology.org/whatis psychology.html

Miles, E. (2010). In-service elementary teachers' familiarity, interest, conceptual knowledge, and performance on science process skills. Unpublished Master Thesis. Southern Illinois University Carbondale.

Mirana, V. P. (2019). Attitude towards science and process skills of junior high school students. Asia Pacific Journal of Multidisciplinary Research, 7(2), 16-23.

Monica, K. (2005). Development and validation of a test of integrated science process skills for the further education and training learners. Unpublished Master's thesis, University of Pretoria. South Africa.

Ngoh, T. (2019). Mastery of the science process skills. Unpublished manuscript.

Oludipe, B., \& Oludipe, D. (2010). Effect of constructivist-based teaching strategy on academic performance of students in integrated science at the junior secondary school level. Educational Research and Reviews, 5(7), 347-353.

Opulencia, L. M. (2011). Correlates of science achievement among grade-VI pupils in selected elementary schools San Francisco District, Division of San Pablo City. Laguna State Polytechnic University.

Ozgelen, S. (2012). Students science process skills within a cognitive domain framework. EURASIA Journal of Mathematics, Science\& Technology Education, 8(4), 283- 292. https://doi.org/10.12973/eurasia.2012.846a

Panoy, B. R. P. (2013). Differentiated strategy in teaching and skills development of pupils in elementary science. Master's Thesis. Laguna State Polytechnic University, San Pablo City Laguna.

Piaget, J. (1983). Handbook of child psychology.

Potvin, P. (2014) Interest, motivation and attitude towards science and technology at K-12 levels: a systematic review of 12 years of educational research. Studies in Science Education.

Ramos-Samala, H. (2018). Spiral progression approach in teaching science: A case study. In 4th International Research Conference on Higher Education, KnE Social Sciences; Polytechnic University of the Philippines.

Rauf, R., Rasul, M., Mansor, A., Othman, Z., \& Lyndon, N. (2013). Inculcation of science process skills in a science classroom. Asian Social Science, 9(8).

Regan, A., \& DeWitt, J. (2015). Attitudes, interest and factors influencing STEM enrollment behaviour: An overview of relevant literature. In E.K. Henriksen, J. Dillon, and J. Ryder (Eds.). Understanding student participation and choice in science and technology education (pp. 63-88). Springer. https://doi.org/10.1007/978-94-007-7793-4_5

Sanja, R. Mulasi, M., \& Ruso, A. (2012). Developing positive attitude towards science and mathematics through motivational classroom experiences. Science Education International, 23(1). 6-19.

Schruba, A. E. (2008). Evaluation of student attitude toward science and self-efficacy in a non-majors college biology course. Master's thesis.

SEED: Collected Papers. Retrieved from http://ecrp.uiuc.edu/beyond/seed/worth.html

Şen, A. Z., \& Nakipoğlu, C. (2012). Analyze of high school chemistry textbooks in terms of science process skills.

Stocké, V. (2016). Attitudes toward surveys, attitude accessibility and the effect on respondents' susceptibility to nonresponse. Qual Quant 40, 259-288. https://doi.org/10.1007/s11135-005-6105-z

Tytler, R., \& Osborne, J. (2012). Student attitudes and aspirations towards science. In B. Fraser, K. Tobin, and C. McRobbie (Eds), Second international handbook of science education. Springer. https://doi.org/10.1007/978-1-4020-9041-7_41

Ungar, S. J. (2010). Seven major misperceptions about the liberal arts. The Chronicle of Higher Education.

Ural, E., \& Gençoğlan, D. M. (2020). The effect of argumentation-based science teaching approach on 8th graders' learning in the subject of acids-bases, their attitudes towards science class and scientific 
Tinapay, A., Tirol, S., Cortes, J. A., \& Punay, M.

process skills. Interdisciplinary Journal of Environmental and Science Education, 16(1), e02207. https://doi.org/10.29333/ijese/6369

von Stumm, S., \& Plomin, R. (2014). Socioeconomic status and the growth of intelligence from infancy through adolescence. US National Library of Medicine.

Worth, K. (2010). Science in early childhood classrooms: Content and process.

Yager, R. E., \& Akçay, H. (2010). The advantages of an inquiry approach for science instruction in middle grades. School Science \& Mathematics, 110, 5-12.

Zeidan, A. H., \& Jayosi, M. R. (2015). Science process skills and attitudes toward science among Palestinian secondary school students. World Journal of Education.

Zeyer, A. (2017). Gender, complexity, and science for all: Systemizing and its impact on motivation to learn science for different science subjects. Journal of Research in Science Teaching.

https://doi.org/10.1002/tea.21413

Zulirfan, Z., Rahmad, M., Yennita, Y., \& Kurnia, N. (2018). Science process skills and attitudes toward science of lower secondary students of Merbau Island: A preliminary study on the development of maritime based contextual science learning media. Journal of Education Sciences, 2(2), 90. 